\title{
Briefing: Potential of energy saving partnerships in the UK: an example of Berlin
}

1 Ksenia Chmutina PhD, MA

Research Associate, Loughborough University, UK

2 Chris I. Goodier BEng, PhD, Pg, Cert, MCIOB, MICT, FHEA

Senior Lecturer in Civil Engineering, Loughborough University, UK
3 Susanne Berger Dipl, Ing

Senior Consultant, Berlin Energy Agency, Berlin, Germany
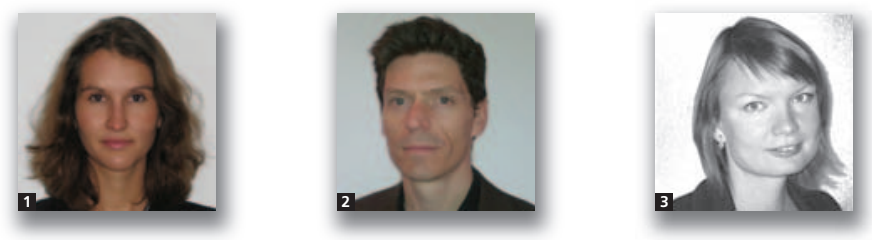

There is significant potential for improving the energy efficiency of the UK's public building stock. This will require, however, significant financial investment by local and national government, which in the current economic climate is very difficult. One way to reduce the energy consumption of public buildings without direct up-front financing is by way of an energy saving partnership (ESP), two examples of which are outlined and compared here: the Berlin Energy Saving Partnership and the London Re:fit programme. Based on these examples and on discussions with UK building retrofit specialists, this paper analyses drivers and barriers for the potential of ESPs in the UK. It emphasises that in order to minimise or prevent potential financial obstacles, strong support, and not just financial support, from local government is required.

\section{Introduction}

Many studies have shown that there is potential for energy efficiency to contribute towards carbon dioxide emissions reductions, particularly from the building stock (Goodier and Pan, 2011; GOS, 2008). Although many energy efficiency projects have already demonstrated their potential high financial returns, many others have not yet reached the stage of attracting significant investment (Painuly et al., 2003). One of the main barriers is the lack of appropriate financial mechanisms. Energy service companies (Escos) have the potential to remove this barrier. This paper presents a successful German energy saving partnership (ESP) and discusses the potential of using similar approaches in the UK.

\section{ESPs as a financial mechanism}

ESPs, also known as energy performance contracting (EPC) (EC, 2011a), are a proven and cost-efficient instrument for energy saving potential in the buildings sector (Xu et al., 2011). Escos are private or public companies that provide the technical and financial services needed for energy efficiency projects: they implement a customised energy service package, consisting of planning, building, operation and maintenance, optimisation, and user behaviour. Depending on their agreement with the client, Escos take project performance risks, arrange, and may also take the client's credit risk. This is done through a performance contract, which can either be in the form of a shared savings contract or a guaranteed savings contract (Painuly et al., 2003). The contract between the Esco and the building owner contains guarantees for cost savings and takes over the financial and technical risks of implementation and operation for the entire project duration, typically of 5 to 15 years. The EPC service or main parts of it is paid for by realised energy cost savings (BEA, 2008).

\section{Berlin Energy Saving Partnership (BESP)}

Although EPCs are widely known in Germany, currently only around 20 Escos (out of 500) are involved in ESPs, including former municipal utilities and multinational companies such as Siemens Building Technologies, Cofely and Johnson Controls.

The BESP was first introduced by the State of Berlin in 1995 . The concept is based on transferring energy management of state-owned properties to a partner, who uses private capital to self-finance the modernisation of the building infrastructure 
necessary to cut energy use. In return, the partner guarantees annual energy cost savings for the state (Berger, 2012). The current BESP includes schools, kindergartens, office buildings, swimming pools, theatre, universities and other municipal buildings such as Red Hall (Figure 1). Implemented energy efficiency measures include refurbishment of heating, ventilation, cooling and illumination, energy management and user motivation

The reason for developing BESP was to contribute towards Berlin's ambitious climate protection objectives, as well as to reduce energy costs for the State of Berlin. Its basic principle is simple: an Esco brings its expertise and financial backing to the project. The responsibility of the contractor is to ensure that, by making adequate investments, the energy savings can be guaranteed. Both partners then share cost reductions, and profits are also shared between the client and the contractor while energy consumption is reduced.

This model has proven to be a success in Berlin and is now widely replicated in Slovenia, Romania, Czech Republic, Chile and other countries (Berger, 2012). The next step in the development of BESP is Energy Saving Partnership Plus, with an aim to extend the focus of the partnership into comprehensive building refurbishment with enhanced shared financing models.

\section{Situation in the UK}

Although not widely known, ESP has been introduced in locations in the UK. One such programme is the Re:fit building energy efficiency programme created by the Greater London Authority in 2010 (EC, 2011b). The Re:fit programme

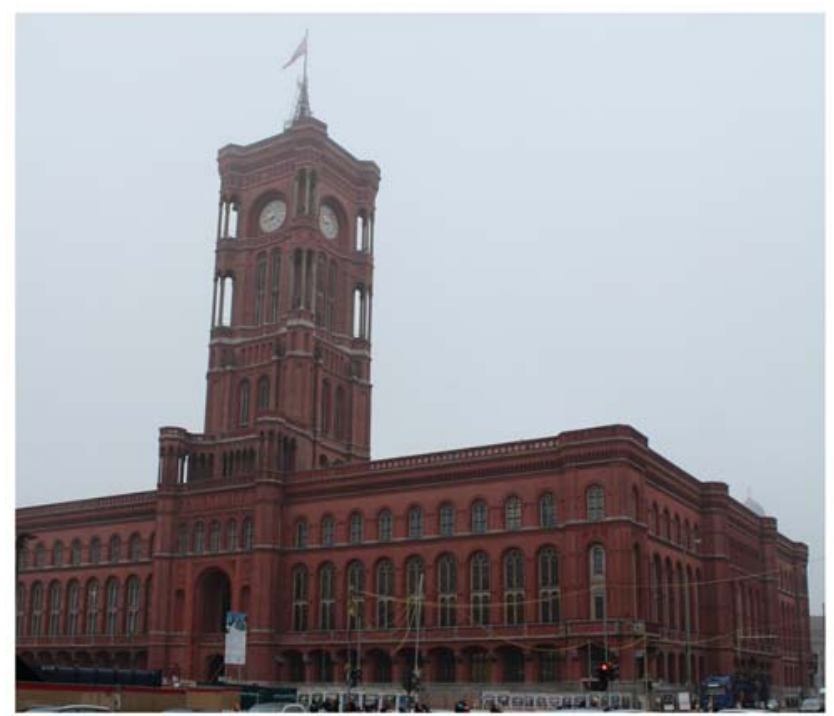

Figure 1. Berlin's Red Hall refurbished under the BESP works similarly to the BESP: it transfers the risk of energy savings from improvements onto the Esco and guarantees a return over an agreed period.

The aim of the programme is to tackle two of the main barriers currently facing the public sector: capacity and capital. It also contributes towards London's target of $60 \%$ carbon reductions by 2025 (EC, 2011b). Energy saving measures have been implemented in a variety of buildings including the London Fire Brigade, London Transport Agency and the London Metropolitan police.

This programme has also already been replicated in other UK cities; Leeds and Sheffield are currently using the framework, and Southampton, Portsmouth, Milton Keynes, Reading and Oxford are also planning to proceed with Re:fit (EC, 2011b; GLA, 2011).

Providers of ESP in the UK include Honeywell Control Systems Ltd, who act as an Esco as well as a facilitator, E.ON Sustainable Energy Business and Cofely, among others.

\section{Potential of ESPs in the UK}

A comparison of BESP and Re:fit (Table 1) shows that, although the UK has the potential for implementing ESPs (and significant efforts have been made in this area), the investment is still comparatively low compared with other on-going successful ESPs.

In order to discuss the potential for ESPs in the UK, a workshop (see http://www.ucl.ac.uk/clues/files/Berlin_report) was held in January 2012 as part of the Challenging lock-in through urban energy systems (Clues) research project (see http://www.ucl.ac.uk/ clues) (Chmutina and Goodier, 2012; Rydin et al., 2010) in order to bring together UK and German practitioners, policy-makers, consultants and academics to discuss the potential of ESPs in the UK context, and to identify the main drivers and barriers for implementing ESPs in the UK. As the workshop findings illustrate in Table 2, the potential for ESPs in the UK has some similarities with the experience of the BESP implementation.

\section{Drivers for implementing ESP in the UK}

The London Re:fit programme and its replication in other UK cities shows that there is obviously some potential for implementing such approaches in the UK. The main driver for this is similar to BESP - cost savings for the local government. It is clear that in the case of ESPs the financial driver is the most crucial one. In addition, local governments in the UK now face the challenge of reducing their carbon dioxide emissions while simultaneously cutting their overall budgets. ESPs allow just that: it saves money while reducing the carbon dioxide emissions of the public buildings. 


\begin{tabular}{lll} 
& BESP & London Re:fit \\
\hline Number of contracts & 26 pools ( 1400 buildings) & 42 buildings $\left(145852 \mathrm{~m}^{2}\right)$ \\
Guaranteed savings (all contracts) & $£ 9 \cdot 6$ million/year (including $€ 2 \cdot 7$ million/year savings in & $£ 1$ million/year \\
& Berlin public budget) & $7000+$ t/year \\
Carbon dioxide emissions reduction & 67900 t/year & $£ 7$ million \\
Investment (all contracts) & $£ 42 \cdot 6$ million & $£ 356$ billion
\end{tabular}

Table 1. Comparison of the BESP and London Re:fit results

\begin{tabular}{|c|c|c|c|c|}
\hline \multirow[b]{2}{*}{ Aspect } & \multicolumn{2}{|c|}{ Potential for the implementation in the UK } & \multicolumn{2}{|c|}{ Experienced in the BESP } \\
\hline & Barrier & Drivers & Barriers & Drivers \\
\hline \multirow[t]{2}{*}{ Financial } & Financial constrains & Energy costs savings & Financial constrains & $\begin{array}{l}\text { Cost reduction for } \\
\text { the local government }\end{array}$ \\
\hline & $\begin{array}{l}\text { High costs of EE measures } \\
\text { Lack of business model } \\
\text { for Escos }\end{array}$ & High fuel prices & Financial risks for Escos & \\
\hline \multirow[t]{4}{*}{ Governance } & $\begin{array}{l}\text { Lack of government } \\
\text { involvement } \\
\text { Lack of clear aims of } \\
\text { the policies }\end{array}$ & $\begin{array}{l}\text { Support of the local } \\
\text { government } \\
\text { National and EU carbon } \\
\text { targets }\end{array}$ & $\begin{array}{l}\text { Lack of facilitation on } \\
\text { the national scale } \\
\text { Hard to identify pools }\end{array}$ & $\begin{array}{l}\text { Interest/support from } \\
\text { the City of Berlin } \\
\text { Climate change } \\
\text { targets }\end{array}$ \\
\hline & $\begin{array}{l}\text { Municipalities do not } \\
\text { have staff/capacity }\end{array}$ & $\begin{array}{l}\text { New business } \\
\text { opportunity }\end{array}$ & $\begin{array}{l}\text { Lack of high quality } \\
\text { specialists }\end{array}$ & \\
\hline & $\begin{array}{l}\text { Lack of familiarity } \\
\text { with performance } \\
\text { contracting } \\
\text { Lack of accreditation } \\
\text { and liability }\end{array}$ & $\begin{array}{l}\text { Energy security and } \\
\text { resilience }\end{array}$ & $\begin{array}{l}\text { Lack of co-operation } \\
\text { from building } \\
\text { technical staff }\end{array}$ & \\
\hline & Complicated regulations & Creation of jobs & & \\
\hline \multirow[t]{6}{*}{ Technical } & Small size of projects & $\begin{array}{l}\text { Poor quality of the } \\
\text { existing building stock }\end{array}$ & $\begin{array}{l}\text { Lower saving potential } \\
\text { of new buildings }\end{array}$ & $\begin{array}{l}\text { Poor quality of } \\
\text { the existing stock }\end{array}$ \\
\hline & $\begin{array}{l}\text { Lack of awareness } \\
\text { of the EE potential }\end{array}$ & $\begin{array}{l}\text { Desire for thermal } \\
\text { comfort }\end{array}$ & $\begin{array}{l}\text { Need in further EE } \\
\text { measures }\end{array}$ & \\
\hline & $\begin{array}{l}\text { Lack of skills and } \\
\text { technical competence }\end{array}$ & & $\begin{array}{l}\text { Limitations to what } \\
\text { can be done }\end{array}$ & \\
\hline & Lack of competence & & & \\
\hline & within the supply chain & & & \\
\hline & Diversity of the building stock & & & \\
\hline \multirow[t]{4}{*}{ Social } & $\begin{array}{l}\text { EE measures are seen as } \\
\text { disruptive }\end{array}$ & $\begin{array}{l}\text { Understanding of non- } \\
\text { financial benefits of EE }\end{array}$ & Lack of understanding & \\
\hline & $\begin{array}{l}\text { Investing in EE is } \\
\text { not a priority }\end{array}$ & $\begin{array}{l}\text { Word of mouth and } \\
\text { exemplar cases }\end{array}$ & Lack of interest & \\
\hline & Rebound effect & & Rebound effect & \\
\hline & $\begin{array}{l}\text { Lack of trust in those } \\
\text { carrying out EE measures }\end{array}$ & & & \\
\hline
\end{tabular}

Table 2. Comparison of the main barriers and drivers for Escos in the UK with the BESP experience 
It is not, however, the only driver. It was discussed that ESPs in the UK can also be encouraged by their ability to create new business niches - not only for the private sector but for the utilities, which can also lead to the creation of new jobs.

The interest and involvement of the local government is obviously vital, particularly at the early stages of a project is it crucial as it enhances trust in the project by the businesses involved and provides important access to the public buildings that require retrofitting.

The general overall low quality of the majority of the UK building stock also presents an enhanced opportunity for ESPs. Owing to their general low energy performance, their energy saving potential is very high, and these savings can also be achieved by implementing 'soft' energy efficiency measures, such as building control; heating, ventilation and airconditioning systems improvement and building-user behaviour change. Additionally, these measures do not require significant technical disruptions - often quoted as one of the main barriers to the implementation of energy efficiency measures.

\section{Barriers for implementing ESPs in the UK}

The main issue Escos face in the UK is the lack of familiarity with its concept owing to the difficulty of accessing finance outside Greater London as the majority of local authorities have tighter budgets as regards the implementation of energy efficiency measures. Financial constraints are a common barrier faced by the Escos, because when the guaranteed savings are not fulfilled, the Escos will bear the losses.

Both BESP and Re:fit showed that the support and involvement of the local government is crucial. This support, however, is an issue for many Escos, as local authorities simply do not have the capacity and capability to be involved. The workshop discussions emphasised that Escos in the UK also lack qualified labour for carrying out and facilitating the projects, which affects negatively the level of the guaranteed savings.

A crucial part of ESPs is the involvement of the building users. The BESP still organises workshops with occupiers in order to explain the ways of reducing energy consumption via small changes in behaviour. Escos control this while the project is being carried out; however, once the project is finished, energy consumption often rises back up due to the lack of control and people's lack of interest in energy savings, as it does not affect them personally - particularly in public buildings, where building users do not pay the energy bills.

\section{Conclusions}

The UK public building stock has significant potential for energy consumption reduction, which implementing ESP approaches could help achieve. Although there is theoretical potential, practical issues still have to be addressed.

Many of the barriers and drivers that are currently being experienced in the UK have already been experienced in the BESP, which could therefore be used as a potential learning example for new ESPs in the UK.

For projects such as ESPs, government support is crucial. The government not only needs to provide support in market development, but also has to act as a customer, information provider and policy maker in order to promote the formation of Escos. This will thus increase the familiarity of working with ESPs in the UK and hence increase trust in the potential of the projects, not only financial but also user-comfort related.

In addition, like any project, the successful implementation of ESPs depends largely on careful planning and development of all involved: all stakeholders are encouraged to participate in the project from its inception, thus allowing high levels of information transfer and transparency.

\section{REFERENCES}

BEA (Berlin Energy Agency) (2008) International Experiences with the Development of Escos Markets. Report for the German Technical Cooperation, Berlin. See http://www. gtz.de/de/dokumente/en-International-ExperienceDeveloping-Esco-Markets.pdf (accessed 14/08/2012).

Berger S (2012) Performance contracting: Energy Saving Partnership - a Berlin success model. Presentation at CLUES Workshop, University of Nottingham, UK. See http://www-staff.lboro.ac.uk/ cvkc2/CLUES\%20BESP\% 20workshop_Presentation_SusanneBerger.pdf (accessed 14/08/2012).

Chmutina K and Goodier Cl (2012) Case study analysis of urban decentralised energy systems. Proceedings of the International Conference on Technology Transfer and Renewable Energy, Mauritius (Leal W (ed.)), pp. 501-516.

EC (European Community) (2011a) Proposal for a Directive of the European Parliament and of the Council on energy efficiency and repealing directives 2004/8/EC and 2006/32/ EC. Official Journal of the European Communities COM/ 2011/0370 final - COD 2011/0172.

EC (2011b) Re:fit. London Development Agency, London, UK. See http://www.managenergy.net/resources/1424 (accessed 14/08/2012).

GLA (Greater London Authority) (2011) Re:fit, London, UK. See http://www.london.gov.uk/priorities/environment/ climate-change/energy-efficiency/buildings-energyefficiency-programme (accessed 14/08/2012).

Goodier Cl and Pan W (2010) The Future of UK Housebuilding. RICS, London, UK.

GOS (Government Office for Science) (2008) Powering our Lives: Sustainable Energy Management and the Built Environment. 
Final project report. Government Office for Science, London, UK. See www.foresight.gov.uk (accessed 14/08/ 2012).

Painuly JP, Park H, Lee, MK and Noh J (2003) Promoting energy efficiency financing and Escos in developing countries: mechanisms and barriers. Journal of Cleaner Production 11(6): 659-665.

Rydin Y, Devine-Wright P, Goodier Cl et al. (2010) Briefing:
Challenging lock-in through urban energy systems (CLUES). Proceedings of the Institution of Civil Engineers Urban Design and Planning 163(4): 149-151, http:// dx.doi.org/10.1680/udap.2010.163.4.149.

Xu PP, Chan EHW and Qian QK (2011) Success factors of energy performance contracting for sustainable building energy efficiency retrofit of hotel buildings in China. Energy Policy 39(1): 7389-7398.

\section{WHAT DO YOU THINK?}

To discuss this briefing, please email up to 500 words to the editor at journals@ice.org.uk. Your contribution will be forwarded to the author(s) for a reply and, if considered appropriate by the editorial panel, will be published as discussion in a future issue of the journal.

Proceedings journals rely entirely on contributions sent in by civil engineering professionals, academics and students. Papers should be 2000-5000 words long (briefing papers should be 1000-2000 words long), with adequate illustrations and references. You can submit your paper online via www.icevirtuallibrary.com/content/journals, where you will also find detailed author guidelines. 